\title{
DAMPAK PEMBANGUNAN KAWASAN DESTINASI WISATA BENDUNGAN KARANGKATES BAGI MASYARAKAT DESA KARANGKATES KABUPATEN MALANG
}

\author{
Mochamad Aan Sugiharto \\ Program Studi Sosiologi, Fakultas Ilmu Sosial dan Ilmu Politik, Universitas \\ Muhammadiyah Malang \\ Email : aansugiharto@umm.ac.id
}

\begin{abstract}
Abstraksi
Penelitian Dampak Pembangunan Kawasan Destinasi Wisata Bendungan Sutami di Desa Krangkates Kecamatan Sumberpucung Kabupaten Malang ini bertujuan untuk melihat bentukbentuk perubahan sosial dan bagaimana perubahan sosial terjadi pada masyarakat Desa Karangkates setelah dibangunnya Bendungan Sutami dan menjadi kawasan destinasi wisata. Untuk itu, subjek penelitian pada penelitian ini adalah warga masyarakat Desa Karangkates yang telah tinggal sebelum Bendungan Sutami dibangun, juga warga Desa Karangkates yang menjadi pedagang maupun yang memanfaatkan Bendungan Sutami sebagai destinasi wisata. Untuk mendapatkan data yang diperlukan, penelitian ini menggunakan metode penelitian deskriptif dengan pendekatan kualitatif yaitu dengan melakukan observasi, wawancara mendalam dan studi literatur termasuk mendapatkan informasi dari data monografi desa. data monografi desa diperlukan untuk melihat informasi terkait masyarakat Desa Karangkates secara periodik termasuk data pekerjaan masyarakat Desa karangkates sebelum dan sesudah pembangunan bendungan. Hasil dari penelitian ini adalah masyarakat sekitar memanfaatkan bendungan sebagai jalan alternatif, sumber air bersih dan sumber energi. Lebih jauh, bendungan yang telah dijadikan sebagai destinasi wisata memberikan mata pencaharian baru bagi masyarakat sekitar, sehingga perekonomian masyarakat yang sebelumnya hanya bergantung pada sektor pertanian menjadi semakin beragam.
\end{abstract}

Kata Kunci: Destinasi Wisata, Karangkates, Pembangunan Bendungan, Perubahan Sosial.

\begin{abstract}
This research on the impact of the development of the Sutami Dam Tourism Destination Area in Krangkates Village, Sumberpucung District, Malang Regency, aims to see the forms of social change and how social change occurs in the Karangkates Village community after the construction of the Sutami Dam and it has become a tourist destination area. For this reason, the research subjects in this study were residents of the Karangkates Village community who had lived before the Sutami Dam was built, as well as Karangkates Village residents who were traders or who used the Sutami Dam as a tourist destination. To obtain the necessary data, this study used a descriptive research method with a qualitative approach, namely by conducting observations, in-depth interviews and literature studies including obtaining information from village monograph data. Village monograph data is needed to view information related to the Karangkates Village community periodically including data on the work of the Karangkates Village community before and after the dam construction. The result of this research is that the surrounding community uses the dam as an alternative way, a source of clean water and a source of energy. Furthermore, dams that have been used as tourist destinations provide new livelihoods for the surrounding community, so that the economy of the people who previously only depended on the agricultural sector became increasingly diverse.
\end{abstract}

Keywords: Tourist Destinations, Karangkates, Dam Development, Social Change.

/ POPULIKA/ Vol. 8 No. 2 Tahun 2020 


\section{Pendahuluan}

Perubahan akan selalu terjadi di setiap kehidupan masyarakat, baik yang terjadi secara natural maupun yang terjadi karena ciptaan manusia. Perubahan yang terjadi karena ciptaan manusia salah satunya adalah perubahan yang terjadi akibat pembangunan suatu bangunan ataupun destinasi wisata. Salah satu yang mengalami perubahan akibat pembangunan destinasi wisata adalah wilayah Desa Karangkates Kecamatan Sumberpucung, Kabupaten Malang. Dengan dibangunnya bendungan Sutami, diiringi juga dengan pembangunan dua destinasi wisata yaitu taman wisata karangkates dan taman wisata lahor. Akibatnya, masyarakat sekitar mengalami perubahan sosial. Perubahan sosial di sini bisa dilihat dari berbagai aspek, ulai dari perubahan kehidupan sosial masyarakat, mata pencaharian maupun dari ekonomi.

Keadaan yang disebutkan di atas disebut juga dengan perubahan sosial, yaitu perubahan yang terjadi di dalam atau mencakup sistem sosial. Lebih tepatnya, terdapat perbedaan antara keadaan sistem tertentu dalam jangka waktu berlainan (Piotr Sztompka: 2014). Bendungan Karangkates atau biasa disebut dengan Bendungan Sutami terletak di Desa Karangkates, Kecamatan Sumberpucung, Kabupaten Malang. Bendungan Karangkates merupakan bendungan dari aliran sungai Brantas yang bersumber dari mata air Gunung Arjuno. Bendungan Karangkates mulai dibangun oleh pemerintah antara tahun 1975-1977 dan diresmikan oleh Presiden Soeharto pada tahun 1977 untuk dijadikan sebagai Pembangkit Listrik Tenaga Air (PLTA). Selain digunakan sebagai PLTA, bendungan ini telah menjadi salah satu obyek pariwisata di Malang.

Bendungan Karangkates yang dikelola oleh Perum Jasa Tirta I (PJT I) yang berkedudukan di Kota Malang. Wisata Karangkates mempunyai dua lokasi taman wisata, yaitu taman wisata Karangkates yang terletak di sebelah utara waduk Sutami dan taman wisata Lahor yang terletak di sebelah selatan waduk Lahor. Bendungan Lahor yang dibangun di atas sungai Lahor letaknya berhimpitan dengan bendungan Sutami. Bendungan Lahor lebih indah dan produksi ikannya juga lebih banyak dibandingkan dengan bendungan Sutami karena tingkat pencemaran di sungai Lahor lebih rendah dari sungai Brantas.

Bendungan Lahor dibangun tahun 1972, dan mulai beroperasi sejak November 1977 merupakan bagian dari proyek pengembangan wilayah sungai Brantas yang dilaksanakan secara terpadu oleh Badan Proyek Brantas atau Badan Pelaksana Induk Pengembangan Wilayah Sungai Brantas. Waduk Lahor ini dialiri oleh tiga buah sungai yaitu sungai Lahor, sungai Leso dan sungai Dewi. Waduk ini terletak kurang lebih 1,5 kilometer di sebelah utara proyek serbaguna Karangkates, dan kurang lebih 32 kilometer di sebelah selatan kota Malang ke arah kota Blitar.

Bendungan ini menjadi salah satu inlet(daerah aliran masuk) dari waduk Sutami yang merupakan waduk terbesar di Jawa Timur. Sejak dibangunnya Bendungan Sutami yang dikelola oleh Perum Jasa Tirta I, maka perubahan banyak terjadi pada masyarakat sekitar, khususnya masyarakat Karangkates. Hal tersebut karena telah terjadi perubahan yang signifikan pada masyarakat Karangkates. Hal tersebutlah yang membuat peneliti tertarik untuk melihat sejauh mana perubahan sosial yang terjadi pada masyarakat sekitar Bendungan Sutami. Sehingga pada penelitian ini yang menjadi pertanyaan peneliti adalah bagaimana dampak dibangunnya destinasi wisata Bendungan Karangkates pada masyarakat Desa Karangkates.

\section{Metode}


Penelitian ini merupakan penelitian kualitatif dengan pendekatan deskriptif, pengumpulan data dilakukan dengan observasi dan wawancara. Karena situasi pandemi yang belum mereda, maka wawancara dilakukan secara virtual melalui whatsapp dan zoom dengan pengelola wisata bendungan karangkates. Wawancara difokuskan pada informasiinformasi terkait kondisi sosial ekonomi masyarakat Desa Karangkates sebelum dan sesudah dibangunnya Bendungan, kemudian data yang diperoleh dianalisis menggunakan teori perubahan sosial.

Ketertarikan peneliti pada tema perubahan sosial masyarakat Desa Karangkates setelah dibangunnya Bendungan Sutami karena ketika di suatu wilayah terdapat perubahan yang cukup signifikan, tentu akan membawa dampak atau pengaruh kepada warga yang berada di sekitarnya. Hal tersebut tak lepas dari perspektif fakta sosial di mana kondisi di luar individu sangat berpengaruh pada kehidupan individu tersebut. Berangkat dari perspektif tersebut, maka peneliti yakin bahwa pada pembangunan Bendungan Sutami, pastilah memiliki dampak terhadap kehidupan sosial warga sekitar yaitu masyarakat Desa Karangkates.

Selain dari persepektif di atas, ketertarikan peneliti pada tema ini adalah karena tematema tentang perubahan sosial masyarakat akibat dari pembangunan telah banyak dilakukan, seperti yang dilakukan oleh Nastassja Virginia Pongantung dalam penelitiannya yang berjudul Perubahan Sosial Budaya Dan Ekonomi Masyarakat Kampung Arborek Kabupaten Raja Ampat Setelah Menjadi Kawasan Wisata. Hasil dari penelitiannya adalah perubahan dalam bidang pendidikan, ketersediaan aliran listrik, tempat tinggal dan perilaku masyarakat terhadap lingkungan. Di sini terlihat bahwa dengan berubahnya kampung Arborek menjadi desa wisata adalah positif kecuali pada perilaku masyarakat terhadap lingkungan yang cenderung negatif dan berdampak buruk terhadap lingkungan.

Penelitian berikutnya dilakukan oleh Harry Hermawan yang berjudul Dampak Pengembangan Desa Wisata nglanggeran Terhadap Sosial Budaya Masyarakat Lokal. Hasil dari penelitian ini adalah terjadinya perubahan yang cukup signifikan bagi kehidupan sehari-hari masyarakat setempat terutama pada aspek kepadatan penduduk, kemacetan lalu lintas dan terjadinya vandalisme pada benda-benda yang berada di sana.

Penelitian berikutnya dilakukan oleh Sani Alim Irhamna yang berjudul Dampak Pengembangan Pariwisata Terhadap Perekonomian Masyarakat Sekitar Objek Wisata di Dieng Kabupaten Wonosobo. Hasil dari penelitian ini adalah dengan dibangunnya objek wisata dapat meningkatkan perekonomian masayrakat sekitar. Namun di balik itu terdapat sisi negatif yaitu tingkat keamanan dan kebersihan yang masih dikatakan buruk.

Kemudian penelitian yang dilakukan oleh Ise Afitah dengan judul Perubahan sosial ekonomi sebagai dampak dari pariwisata taman nasional tanjung puting (studi kasus di kelurahan kumai hulu kecamatan kumai kabupaten kotawaringin barat). Hasil dari penelitian ini adalah di Kabupaten Kotawaringin Barat setelah adanya Taman Nasional Tanjung Puting perekonomian masyarakat semakin meningkat dan berdampak pada pola pikir masyarakat yang semakin sadar dengan potensi yang dimiliki oleh tempat tinggalnya.

Dari keempat penelitian di atas, bisa dikatakan bahwa keempatnya mendapatkan hasil bahwa dalam sebuah pembangunan objek wisata, selalu terdapat hal positif dan negatif dari sebuah pembangunan dan pengembangan objek wisata. Hal tersebut semakin membuat peneliti yakin bahwa hal yang serupa juga pasti bisa terjadi di setiap tempat lain yang mengalami pembangunan tempat wisata termasuk di Desa Karangkates Kecamatan Sumberpucung Kabupaten Malang.

Subyek Penelitian pada penelitian ini adalah masyarakat Desa Karangkates, Kecamatan Sumberpucung Kabupaten Malang. Subjek penelitian dipilih menggunakan 
metode purposive yaitu masyarakat Desa Karangkates yang telah tinggal sebelum dibangunnya Bendungan sampai dengan saat ini, hal ini karena merekalah yang nantinya bisa memberikan informasi yang dibutuhkan terkait perubahan sosial yang terjadi setelah pembangunan bendungan. Selain itu, subjek juga diambil dari masyarakat Desa Karangkates yang memanfaatkan bendungan, seperti masyarakat yang menjadi pedagang di tempat wisata di sekitar bendungan. Dikarenakan situasi ketika penelitian dilakukan adalah masih terjadi pandemi Covid-19, maka subjek penelitian ini adalah 2 orang pegawai divisi wisata di bendungan karangkates yang dikelola oleh Perum Jasa Tirta 1. 2 orang tersebut adalah masyarakat setempat atau masyarakat Karangkates sehingga mereka mengetahui dan memiliki akses langsung untuk mendapatkan data di pemerintah setempat dan di pengelola wisata.

Dalam penelitian ini teknik pengumpulan data yang dilakukan menjadi 2 yaitu data primer dan data sekunder. Data primer dilakukan dengan menggunakan teknik observasi, wawancara mendalam (Depht Interview) kepada masyarakat Desa Karangkates, Kecamatan Sumberpucung Kabupaten Malang. Observasi dilakukan di awal-awal sebelum pandemi covid 19, sementara wawancara mendalam dilakukan secara virtual menggunakan aplikasi zoom dan whatsapp. Data sekunder didapatkan dari studi literatur yang banyak terdapat di jurnal-jurnal penelitian dan data monografi desa yang didapatkan dengan bantuan subjek penelitian.

Dalam penelitian ini, data yang telah berhasil dikumpulkan baik data primer maupun data sekunder akan dikomparasikan dan kemudian dianalisis menggunakan teori perubahan sosial dan dampak sosial. Data tentang kondisi terkini masyarakat Desa Karangkates Kecamatan Sumberpucung Kabupaten Malang setelah dibangunnya Bendungan Sutami dan Bendungan Lahor dikomparasikan dengan data kondisi masyarakat Desa Karangkates Kecamatan Sumberpucung Kabupaten Malang sebelum dibangunnya Bendungan Sutami dan Bendungan Lahor. Dari data tersebut, bisa dilihat perubahan-perubahan yang terjadi dari sebelum dibangunnya bendungan dengan setelah dibangunnya bendungan, termasuk ketika kemudian PJT 1 membuka destinasi wisata di kedua kawasan bendungan tersebut.

\section{Hasil dan Pembahasan}

Tahun 1999 Perusahaan Umum (Perum) Jasa Tirta berubah nama menjadi Perusahaan Umum (Perum) Jasa Tirta I sesuai PP nomor 93 Tahun 1999. PP ini mengandung pengertian strategis, sebab terdapat perencanaan untuk mengembangkan beberapa badan usaha sejenis di wilayah sungai (WS) lain yang memungkinkan. Sebagai tindak lanjut dari peraturan tersebut, pada tahun 2000, Perum Jasa Tirta I kembali ditugaskan oleh pemerintah untuk mengelola Wilayah Sungai Bengawan Solo melalui Keputusan Presiden (Keppres) Republik Indonesia nomor 129 Tahun 2000. Seiring dengan perkembangan kebutuhan nasional untuk mencukupi suplai energi listrik dan air bersih, dasar hukum Perum Jasa Tirta I disempurnakan melalui Peraturan Pemerintah nomor 46 Tahun 2010 tentang Perusahaan Umum (Perum) Jasa Tirta I yang di dalamnya mengatur salah satu tugas dan tanggung jawab Perum Jasa Tirta dalam mengoptimalkan kemanfaatan aset yang dikuasai untuk menghasilkan pendapatan guna menambah pembiayaan pelaksanaan tugas pokok, seperti penyelenggaraan SPAM (Sistem Penyediaan Air Minum) dan penyediaan listrik.

\section{A. Bidang Usaha Perusahaan}

Dalam rangka melaksanakan maksud dan tujuan Perusahaan, Perusahaan melakukan kegiatan usaha sebagai berikut: 
1. Layanan jasa air baku untuk pembangkit tenaga listrik, air minum, industri, pertanian, penggelontoran, pelabuhan, usaha jasa konsultasi di bidang teknologi sumber daya air, penyewaan alat besar, jasa laboratorium lingkungan.

2. Penyediaan tenaga listrik kepada Perusahaan Perseroan (Persero) PT. Perusahaan Listrik Negara dan atau selain Persero PT. Perusahaan Listrik Negara sesuai dengan ketentuan peraturan perundang - undangan.

3. Penyediaan air permukaan untuk kebutuhan pokok sehari - hari, pengendalian banjir, dan konservasi DAS.

4. Pengembangan Sistem Penyedia Air Minum (SPAM) dan sanitasi untuk keperluan rumah tangga.

Selain kegiatan usaha utama, Perusahaan menyelenggarakan usaha optimalisasi potensi sumber daya yang dimiliki Perusahaan untuk pariwisata, perhotelan dan resort, sumber daya energi, air minum dalam kemasan, jasa konsultansi, jasa konstruksi, ekobisnis, pusat pelatihan, usaha pertanian, jasa penyewaan, dan pengusahaan sarana dan prasarana yang dimiliki dan dikuasai Perusahaan

\section{B. Permodalan}

Modal perusahaan merupakan kekayaan Negara yang dipisahkan dari Anggaran Pendapatan dan Belanja Negara dan tidak terbagi atas saham-saham. Dikecualikan dari modal adalah: waduk, bendung, tanggul, terowongan, dan pelurusan sungai.

\section{Dampak Pembangunan Bendungan}

Sejak dibangun pada tahun 1975 sampai dengan tahun 1977, Bendungan Sutami dan Bendungan Lahor memiliki banyak fungsi. Awal ketika dibangun, kedua bendungan memang memiliki setidaknya 2 fungsi utama yaitu sebagai sumber utama air bersih dan sebagai pembangkit energi. Lebih dari itu, pembangunan bendungan juga kemudian berkembang menjadi dibangunnya destinasi wisata yang juga dalam perkembangannya membawa dampak yang besar bagi masyarakat Desa Karangkates Kecamatan Sumberpucung Kabupaten Malang.

Sesuai dengan fungsi dan tujuan awal dibangunnya bendungan, bendungan sutami dan bendungan lahor di wilayah Kecamatan Karangkates memiliki 2 fungsi utama sebagai berikut:

\section{Bendungan Sebagai Sumber Air Masyarakat Karangkates}

Fungsi pertama adalah untuk menjadi sumber air bagi masyarakat khususnya masyarakat Malang Selatan. Berdasarkan wawancara dengan salah satu pengelola Perum Jasa Tirta I divisi bendungan yaitu Eriko, daerah Malang Selatan khususnya Kecamatan Karangkates dan sekitarnya merupakan daerah yang tidak memiliki banyak sumber air, hal tersebut membuat daerah Karangkates dan sekitarnya memiliki permasalahan terkait ketersediaan air. Jika pada musim penghujan sumur dan sungai terdapat air yang melimpah, tetapi jika sudah memasuki musim kemarau maka sumur dan sungai tersebut akan sangat berkurang debit airnya bahkan sampai tidak ada sama sekali. Hal tersebut mengakibatkan masyarakat Kecamatan Karangkates dan sekitarnya mengalami kesulitan akses air ketika musim kemarau tiba, baik untuk kebutuhan rumah tangga maupun untuk keperluan pertanian.

Masyarakat Kecamatan Karangkates mayoritas bermata pencaharian di bidang pertanian, sehingga ketersediaan air untuk menunjang pertaniannya sangatlah penting. Sumber air utama untuk pertanian pada waktu itu adalah dari air hujan dan air sungai atau 
sumur, hal tersebut karena ketika musim penghujan curah air hujan tinggi sehingga sungai masih mengalir air yang cukup deras dan sumur-sumur warga juga masih menampung banyak air. Hal tersebut berubah drastis jika memasuki musim kemarau, di mana ketika tidak ada hujan yang turun dan membuat sungai sungai yang sebelumnya mengalir air menjadi kerin, begitupula dengan sumur sumur yang sebelumnya menampung banyak air menjadi kering. Hal tersebut menjadi persoalan bagi masyarakat, air untuk memenuhi kebutuhan sehari-hari dan keperluan pertanian menjadi tidak tersedia.

Dengan dibangunnya Bendungan Sutami dan Bendungan Lahor di Kecamatan Karangkates membuat ketersediaan air bisa teratasi dan semakin mudah. Sejak dibangunnya kedua bendungan tersebut, sistem penyaluran air untuk keperluan rumah tangga dilakukan dengan manajemen PDAM yang dikelola oleh PJT 1. Air dari Bendungan Sutami maupun Bendungan Lahor disalurkan ke rumah-rumah penduduk menggunakan pipa, sehingga ketersediaan air untuk keperluan rumah tangga tidak akan lagi mengalamai kesulitan karena air diambil langsung dari kedua bendungan. Masyarakat Karangkates tidak perlu lagi mencari air sampai ke luar dari wilayah Kecamatan Karangkates maupun membeli air dari mobil tangki.

Untuk keperluan pertanian, sistem irigasi yang bersumber dari kedua bendungan juga sangat membantu. Saat ini, masyarakat yang bermatapencaharian sebagai petani tidak perlu khawatir jika musim kemarau datang karena ketersediaan air untuk lahannya selalu terpenuhi meskipun tidak ada hujan yang turun. Dengan sistem irigasi dari bendungan, sawah masyarakat tidak lagi tergantung sepenuhnya dari air hujan.

\section{E. Bendungan Sebagai Sumber Energi}

Selain untuk menampung air dan menjadi pemasok air bagi keperluan sehari-hari masyarakat Karangkates, Bendungan Sutami dan Bendungan Lahor yang dibangun di wilayah Kecamatan Karangkates juga berfungsi sebagai sumber energi melalui Pembangkit Listrik Tenaga Air. Dokumen tersebut tertulis dalam peresmian Bendungan pada tahun 1977 oleh Presiden Indonesia pada saat itu yaitu Soeharto. Melalui pembangkit listrik tersebut, Bendungan Sutami dan Bendungan Lahor menjadi salah satu pemasok utama kebutuhan listrik bagi masyarakat Kabupaten Malang khususnya Kabupaten Malang daerah selatan/malang selatan.

Seperti yang telah disebutkan, PJT 1 selaku pengelola kedua bendungan di wilayah Kecamatan Karangkates tersebut telah berhasil membuat Bendungan Sutami dan Bendungan Lahor menjalankan fungsinya dengan baik. Dalam hal ini, fungsi manifest dari dibangunnya bendungan telah berjalan dengan baik. Namun seperti telah diyakini oleh penganut paham fungsionalisme, segala sesuatu pasti memiliki fungsi tambahan yang mengikuti dari fungsi utama. Hal tersebut dikatakan oleh teori fungsionalisme sebagai fungsi laten. Fungsi laten ini merupakan fungsi tambahan yang dalam hal ini yaitu pembangunan bendungan sebagai pemasok sumber air bersih dan pembangkit energi juga dalam perjalanannya memiliki fungsi lainnya, yaitu:

\section{F. Bendungan Sebagai Jalur Alternatif}

Jika dua fungsi yang disebutkan sebelumnya adalah fungsi utama atau fungsi manifes dari Bendungan, bisa dikatakan jika fungsi satu ini merupakan fungsi laten dari kedua bendungan yang dibangun di wilayah Kecamatan Karangkates tersebut, yaitu sebagai jalur atau jalan alternatif. Perlu diketahui jika wilayah Kecamatan Karangkates termasuk wilayah pinggiran Kabupaten Malang dan berbatasan langsung dengan Kabupaten Blitar. 
Sebelum Bendungan Sutami dan Bendungan Lahor dibangun, masyarakat Kabupaten Malang yang ingin pergi ke wilayah Kabupaten Blitar harus menempuh jalur utama yang cukup jauh dan membutuhkan waktu tempuh yang cukup lama. Tidak hanya itu, karena Karangkates merupakan wilayah perbatasan, maka sangat sedikit pusat perekonomian maupun pendidikan yang ada di sana. Hal tersebut menjadikan pergi ke pusat perekonomian dan pendidikan yang notabene terletak di kecamatan merupakan hal yang harus dilakukan. Untuk itu, masyarakat yang tinggal di pinggiran Kecamatan Karangkates jika ingin pergi ke pusat Kecamatan Karangkates harus menempuh jarak yang cukup jauh.

Berdasarkan observasi yang dilakukan, jika melewati jalur utama atau jalur propinsi, waktu tempuh dari wilayah perbatasan seperti Kalipare ke pusat Kecamatan Karangkates membutuhkan waktu 25 menit. Ketika bendungan Sutami telah dibangun, masyarakat Kalipare memanfaatnya juga sebagai jalan alternatif sehingga hanya membutuhkan waktu kurang dari 10 menit untuk bisa sampai ke pusat Kecamatan Karangkates. Begitu pula dengan warga Selorejo Kabupaten Blitar yang memanfaatkan Bendungan Lahor sebagai jalan alternatif ke Kabupaten Malang melalui Karangkates yang sebelumnya jika melewati jalur utama membutuhkan waktu sekitar 30 menit tetapi dengan memanfaatkan bendungan Lahor hanya membutuhkan waktu kurang dari 10 menit.

\section{G. Bendungan Sebagai Mata Pencaharian Baru}

Sejak PJT 1 menjadikan Bendungan Sutami dan bendungan Lahor sebagai destinasi wisata, banyak masyarakat dari luar Kecamatan Karangkates bahkan dari luar Kabupaten Malang yang datang berkungjung ke sana. Banyaknya wisatawan yang datang berkungjung, membuat PJT1 selaku pengelola membangun beberapa wahana dan mengijinkan masyarakat untuk melakukan aktivitas ekonomi di sekitar wisata Bendungan Sutami dan Bendungan Lahor.

\section{Kesimpulan}

Pembangunan Wisata Karangkates selain memiliki fungsi utama sebagai menampung air dan sumber energi alternatif, juga memiliki fungsi-fungsi manifest, yaitu:

1. Sebagai jalan alternatif masyarakat sekitar

2. Sebagai sumber mata pencaharian baru bagi masyarakat karena saat ini sudah tidak banyak yang bermatapencaharian sebagai petani dan beralih menjadi pedagang di sekitar lokasi wisata. Hal tersebut didukung juga dengan kebijakan yaitu lebih memprioritaskan warga sekitar untuk berjualan.

3. Ketika wisata tutup sementara akibat pandemi, masyarakat yang sebelumnya menjadi pedagang di lokasi wisata untuk sementara waktu memilih pekerjaan alternatif dengan tetap berharap bisa kembali melakukan aktivitas ekonomi kembali di lokasi wisata bendungan karangkates.

\section{Daftar Pustaka}

Adisasmita, S.A. (2011). Perencanaan Pembangunan Transportasi. Yogyakarta: Graha Ilmu.

Damsar, D \& Indrayani. (2015). Pengantar Sosiologi Ekonomi (edisi kedua). Jakarta: Kencana.

Hermawan, H. (2016). Dampak Pengembangan Desa Wisata nglanggeran Terhadap Sosial Budaya Masyarakat Lokal. Seminar Nasional Ilmu Pengetahuan dan Teknologi Komputer. ISBN: 978-602-72850-3-3 
Pongantung, N.V. (2018). Perubahan Sosial Budaya Dan Ekonomi Masyarakat Kampung Arborek Kabupaten Raja Ampat Setelah Menjadi Kawasan Wisata. Jurnal AgriSosioEkonomi Unsrat, ISSN 1907-4298, Volume 14(1), 109 -116

Creswell, J.W. (2018). Research Design, pendekatan metode kualitatif, kuantitatif dan campuran. Yogyakarta: Pustaka Pelajar.

Salim, A.(2014). Perubahan Sosial: sketsa teori dan refleksi metodologi kasus indonesia. Yogyakarta: Tiara Wacana Yogya

Sztompka, P.(2014). Sosiologi Perubahan Sosial. Jakarta: Prenada. 